\title{
Relationship of Knowledge of Mother with the Level of Language Development in Children Aged 2-3 Years in Puskesmas Padang Panyang, Nagan Raya
}

\author{
${ }^{1}$ Anasril, ${ }^{1}$ Muhammad Husaini, ${ }^{1}$ Bustami, ${ }^{1}$ Amiruddin \\ ${ }^{1}$ Poltekkes Kemenkes Aceh, Indonesia
}

Coresponding author: Anasril, e-mail: anasrilsuri@gmail.com

Co-author : MH: husainiiskandar77@gmail.com, BB: bustami@ poltekkesaceh.ac.id, AA: amirudinsulaiman65@gmail.com doi: https://doi.org/10.35308/j-kesmas.v7i2.1646. How to cite this article: Anasril. A., Husaini, M., Bustami, B., \& Amiruddin, A. (2021). Relationship of Knowledge of Mother with the Level of Language Development in Children Age 2-3 Years in the Working Area of Public Health Center Padang Panyang, Kuala Pesisir District, Nagan Raya Regency. J-Kesmas: Jurnal Fakultas Kesehatan Masyarakat (The Indonesian Journal of Public Health). 8(1): 36-40.

\begin{abstract}
Stimulation of growth and development, especially language development in children, needs to be done to improve children's ability to speak in accordance with the level of development. The lack of information obtained by mothers about the importance of language stimulation for children causes mothers to consider it normal when a child is able to speak too late. The purpose of this study was to determine the relationship between maternal knowledge and the level of language development in children aged 2-3 years in Puskesmas Pandang Panyang, Nagan Raya. This research is analytical with a crosssectional study design. The number of samples is 100 people taken randomly. The results showed that there was a significant relationship between maternal knowledge about language stimulation and language development in children aged 2-3 years with a value of $\mathrm{p}=0.000$. With Prevalence ratio (PR), namely 31.89. It is recommended that parents increase their knowledge of language stimulation in order to realize language development according to age and child
\end{abstract}

Keywords: Knowledge; Language Stimulation; Language Development.

\section{Introduction}

Language is closely related to the development of individual thinking. The development of the individual mind appears in the development of language, namely the ability to form understanding, compilers, opinions and draw conclusions (Jahja, y. 2011). The development concerns the differentiation process of body cells, body tissues, organs and organ systems that develop in such a way that each can fulfill its function (Jahja, y. 2011). According to Santrock (2007), development is a pattern of change that begins at conception and continues throughout the life span of an individual. According to Soetijingingsih (2014), there are four aspects of development of children under five years of age or toddlers, namely language (Language) which relates to the ability to respond to sounds, follow orders, and speak spontaneously. Children with developmental delays can be trained by frequently communicating with children such as inviting children to talk, reading story books, asking children to repeat words, using props, using hand puppets, helping children succeed in something, making business cards for objects the child mentions, and making hums (Janice Beaty. 2013).
Language skills are a combination of the entire child's developmental system, language skills involve motor, psychological, emotional and behavioral skills. In addition, speech disorders can be caused by physical abnormalities such as cleft lip and cerebral palsy. Stuttering can also occur due to intelligence and family factors. In addition, this disorder is also one of the language development disorders that can be caused by pressure from parents to make children talk. Children can be caused by various factors, namely genetic factors, hearing loss, low intelligence, lack of interaction between children and the environment, late maturation, and family factors (Adriana, 2011). Language development is the ability to communicate with other people. How to communicate can be expressed in the form of symbols to express an understanding by using oral, written, gestures, numbers, paintings, and facial expressions (Yusuf S. 2012).

Language delay in the toddler period has the potential to cause problems in the learning process at school. Children who experience speech delays are at risk of experiencing learning, reading and writing difficulties and can continue into young adulthood (Dewi, VNL. 2013). language delay in toddlers aged 1-3 years is caused by parenting. Parenting can be 
defined as a pattern of behavior that is applied to children and is relatively consistent over time. This pattern of behavior can be suggested by the child,in terms of both negative and positive. There are 3 kinds of parenting styles, namely democratic parenting, authoritarian parenting, and permissive parenting (Anggraini \& Ririn. 2014).

Based on the results of research by Sabrina (2018) entitled The Relationship between Parental Stimulation and Language Development of Children Aged 0-3 Years in the Work Area of the Penengah Raya Poskeskel, Kedaton, Bandar Lampung District. Based on the research results, it is proven that there is a relationship between parental stimulation and language development of children aged 0-3 years. The results of this study indicate that the importance of parental understanding of the stimulation of growth and development in children to stimulate children's ability to language according to age. Knowledge is the result of human sensing, or the result of knowing someone's object through the senses he has (Eyes, nose, ears, etc.). Padang Panyang Health Center is one of the accredited health centers in Nagan Raya Regency. The number of mothers who have toddler age children in the working area of the public health center is 134 people. Based on the results of interviews conducted with 6 mothers who visited the public health center, it was found that a mother who had children aged 1 year and 9 months could not speak, and 5 mothers had children aged 2 - 3 years who could not speak words fluently and could not making sentence. The results of the interview also showed that the mother did not feel that this was a problem for the child's development.The mothers who were interviewed also stated that other people's children did too. Mothers said they did not know anything about language stimulation for their children.

\section{Methods}

This type of research is analytic with a crosssectional study design, which aims to find the relationship between the independent variable and the dependent variable (Narbuko, Kholid, 2010). This study was to determine the relationship between mother's knowledge of language stimulation and the level of language development in children aged 2-3 years in the Padang Panyang Health Center, Kuala Pesisir District, Nagan Raya Regency. The population in this study were all mothers who have children aged 2-3 years who live in the working area of the Public Health Center, totaling 134 people. In this study, the sampling technique used was cluster random sampling, namely by taking representatives from each region (Hastono, 2010).

The number of samples to be taken refers to the Slovin formula, namely:

$$
\begin{aligned}
& n=\frac{\mathrm{N}}{1+\left(\mathrm{N} \cdot \mathrm{d}^{2}\right)} \\
& \frac{134}{1+\left(134 \cdot 0.05^{2}\right)} \\
& \mathrm{n}=\quad 100,37 \approx 100 \text { samples }
\end{aligned}
$$

The tools or instruments used in this research arequestionnaire. For language development using the Standard Development Pre Screening Questionnaire (KPSP). Meanwhile, the mother's knowledge questionnaire uses a questionnaire that has been tested by previous researchers. The number of questions on the knowledge variable was 15 questions.

\section{Results}

\section{Univariate Analysis}

Mother's knowledge of language stimulation is categorized into two categories, namely good and poor categories. It is categorized as good if the score obtained is more than the average score, and less if the score obtained is less than or equal to the average value. Maternal knowledge categories can be seen in the following table 1 :

Table 1. Univariate Analysis

\begin{tabular}{lcc}
\hline Categories & Total & $\mathbf{( \% )}$ \\
\hline Mothers' Knowledge & & \\
Good & 55 & 55 \\
Less & 45 & 45 \\
Language Development & & \\
Suitable & 54 & 54 \\
Unsuitable & 46 & 46 \\
\hline Total & 100 & 100 \\
\hline Sol Pris
\end{tabular}

Source: Primary Data, 2020

From the table above, it can be seen that the majority of respondents have knowledge in the good category about language development, namely 55 people $(55 \%)$, majority of respondents have children with language development appropriate to the child's age 2-3 years, namely 54 people $(54 \%)$.

\section{The Relationship between Mother's Knowledge and Children's Language Development}

Table 3. The Relationship between Mother's Knowledge and Children's Language Development 


\begin{tabular}{|c|c|c|c|c|c|c|c|}
\hline \multirow{3}{*}{$\begin{array}{c}\text { Knowledg } \\
\text { e }\end{array}$} & \multicolumn{4}{|c|}{$\begin{array}{c}\text { Language } \\
\text { Development }\end{array}$} & \multirow{2}{*}{\multicolumn{2}{|c|}{ Total }} & \multirow{3}{*}{$\mathbf{P}$} \\
\hline & \multicolumn{2}{|c|}{$\begin{array}{c}\text { Suitabl } \\
\text { e }\end{array}$} & \multicolumn{2}{|c|}{$\begin{array}{c}\text { Unsuitab } \\
\text { le }\end{array}$} & & & \\
\hline & $\mathrm{n}$ & $\%$ & $\mathrm{n}$ & $\%$ & $\mathrm{n}$ & $\%$ & \\
\hline Good & 47 & 85,5 & 8 & 14,5 & 55 & 100 & \multirow{2}{*}{$0,00031,89$} \\
\hline Less & 7 & 15,6 & 38 & 84,4 & 45 & 100 & \\
\hline Total & 54 & & 46 & & 100 & & \\
\hline
\end{tabular}

Source : Primary Data, 2020

The table above shows that of the 55 mothers who have good knowledge, $85.5 \%$ of them have children with age-appropriate language development. The chi-square test result shows that the value of $p=$ 0.000 ( $\mathrm{p}<0.05$ ). The decision taken was accepted by $\mathrm{Ha}$, meaning that there was a significant relationship between mother's knowledge of language stimulation and language development of children aged 2-3 years. The strength of the relationship or the Prevalence ratio (PR), which is 31.89 , means that mothers who have good knowledge have a 31.89 times greater chance of having children with ageappropriate language development compared to mothers with less knowledge.

\section{Discussion}

The results showed that the knowledge of mothers about language stimulation in children at health center Padang Panyang, Kuala Pesisir District, Nagan Raya Regency was in the good category as many as 55 people (55\%).

Most mothers also received direction and guidance from health workers, especially village midwives during Integrated Healthcare Center days on how to stimulate language development in children who speak late or speak less fluently. Another thing that is supportive is that most of the mothers work as housewives so there is a lot of time for mothers to get information related to child development, including children's language development. In addition, from an educational perspective, most of the mothers who became respondents had an adequate educational background, namely High School. Adequate education will affect a person's ability to gain knowledge about an object.As according to Notoatmotjo (2014) that knowledge is very closely related to education, where it is expected that with high education, the person will have broader knowledge.However, it needs to be emphasized, it does not mean that someone with low education is absolutely low-knowledgeable. Knowledge will affect a person's attitude in acting.A person's knowledge of an object contains two aspects, namely positive aspects and negative aspects. These two aspects will determine a person's attitude, the more positive aspects and objects that are known, it will lead to a positive attitude towards certain objects.According to the WHO (word health organization) theory, one form of health object can be described by knowledge gained from one's own experience (Wawan, 2010).

Although this knowledge is only a closed behavior, knowledge is very important to change behavior for the better.The actions that a person shows in responding to an object of behavior will be greatly influenced by the person's level of knowledge. Therefore, although the percentage of respondents who have good knowledge is higher, efforts are still needed to increase the knowledge of mothers about this language stimulation so that the number will increase in the future.Based on the results of research on language development in children in the working area of the Padang Panyang Health Center, Kuala Pesisir District, Nagan Raya Regency, it was found that most respondents had children with age-appropriate language development, namely 54 people or $54 \%$. In the stages of growth and development, most of the children of mothers who became respondents were in accordance with the stages, although there were differences in different growth and development. Wong (2009) states that the rate of speech development of children varies from child to child, this is related to the nervous system and cognitive.

According to Yektiningsih (2010), a child will not be able to speak without help from the environment. They must hear conversations relating to their daily lives and knowledge of the world.They must learn to express themselves, share their experiences with others and express their desires. However, although in the working area of the health center Padang Panyang, Kuala Pesisir district, there are more children who are suitable for their language development according to their age, efforts to continue to improve children's abilities must be continued, one of which is by providing stimuli or stimuli, especially from their own mothers. To prove whether or not there is a relationship between maternal knowledge about language stimulation and language development of children aged 2-3 years, bivariate analysis using the chi-square test is carried out. From the results of the chi-square test, it was obtained that the value of $p=0.000$, meaning that there is a significant relationship between maternal knowledge about language stimulation and language development of children aged 2-3 years. The Prevalence Ratio value shows a value of 31.89 . This proves that the opportunities for well-informed 
mothers are large enough to improve language development in their children. The results of this study are in accordance with Yudia Putra's (2018) research on the effect of stimulation by parents on language development in toddlers at PAUD Asparaga Malang, with the result $p=0.002$. The results of the analysis show that there is a significant effect of stimulation by parents on language development of toddlers. This study also recommends parents to continue to provide stimulation that supports children's language development so that it is in accordance with the proper stage of growth and development.

In line with the results of the above research, a study conducted by Fauziana (2013) entitled The Relationship Between Mother's Knowledge of Early Stimulation and Language Development of 1-3 Years Old Children in Sangkrah Village,shows that there is a relationship between maternal knowledge about early stimulation and language development of children aged $1-3$ years with $\mathrm{p}=0.000(\mathrm{p}<0.05)$. The level of relationship is moderate and positive $(\mathrm{r}=$ 0.517).The conclusion of this study is that maternal knowledge about early stimulation is needed to improve language development of children aged 1-3 years.

It is known that most of the mother's children have high school education, the researcher believes that this level of education is already at the middle level so that in thinking and digesting a new experience to increase knowledge is more easily accepted. Experience also plays a role in the level of parental knowledge. So, from the results of this study it is concluded that the level of parental knowledge plays an important role as a factor in language development. The higher the level of parental knowledge about language stimulation, the better the language development of their children. A person's knowledge so much affects the emergence of understanding and attitudes which will ultimately lead to one's behavior. The purpose of giving stimulation to children is tohelp children to achieve optimal levels of development or as expected. Based on this, it is evident that the mother's knowledge of language stimulation greatly determines language development in children according to their age and stage of development. Considering that these results are very meaningful for language development in children aged 2-3 years, the researchers recommend that parents become good parents for their children, by increasing knowledge about language stimulation in order to realize language development according to their developmental age, for example by seeking information through print media or electronic media.

\section{Conclusion}

The results of the study found that there was a significant relationship between knowledge of language stimulation and language development in children aged 2-3 years, as evidenced by the results of statistical tests with a value of $p=0.000$ and an Prevalence ratio (PR) of 31.89. Most of the respondents have good knowledge about language stimulation and have children who are appropriate for language development and age

\section{Acknowledgement}

Praise Allah SWT for His guidance and mercy. Thanks to all those who have helped in the research until this journal is published. Thank you to the Aceh Health Department health Polytechnic for research funding assistance.

\section{Author Contribution and Competing Interest}

The first author has the largest contribution in this research, starting from the preparation of proposals to reporting the research results. The second and third authors contributed to the collection, processing and analysis of data and assisted the first author in writing articles.

\section{Publisher's Note}

J-Kesmas: Jurnal Fakultas Kesehatan Masyarakat (Indonesia Journal of Public Health) remains neutral with regard to jurisdictional claims in published institutional affiliation.

\section{References}

Adriana. (2011). Tumbuh Kembang dan Terapi Bermain Pada Anak. Salemba Medika.

Anggraini, R. (2014). Hubungan Pola Asuh Orang Tua dengan Motivasi Belajar Siswa. Jurnal Ilmiah Pendidikan Bimbingan dan Konseling Title. Jurnal Ilmiah Pendidikan Bimbingan Dan Konseling, 21. http://e-journal.ikipveteran.ac.id

Dewi, V. N. L. (2013). Asuhan Neonatus Bayi Dan Anak Balita. Salemba Medika.

Dewi, \& Wawan. (2010). Teori dan Pengukuran Pengetahuan, Sikap dan Perilaku Manusia. Nuha Medika.

Fauziana, S. E. (2013). Hubungan Antara Pengetahuan Ibu Tentang Stimulasi Dini Dengan Perkembangan Bahasa Anak Usia 1-3 
Tahun Di Kelurahan Sangkrah.

Fazriesa, S. (2018). Hubungan Stimulasi Orang Tua Terhadap Perkembangan Bahasa Anak Usia 0-3 Tahun Di Wilayah Kerja Poskeskel Penengahan Raya Kecamatan Kedaton Bandar Lampung.

Hastono, S. P. (2010). Statistik Kesehatan. Rineka.

Jahja, Y. (2011). Psikologi Perkembangan. Kencana Prenada Media Group.

Janice, B. (2013). Observasi Perkembangan Anak Usia Dini. Kencana Prenada Media Group.

Narbuko, K. (2010). Metodologi Penelitian. Rineka Cipta.

Notoatmodjo, S. (2014). Ilmu Perilaku Kesehatan. Rineka Cipta.

Putra, A. Y., Yudiernawati, A., \& Maemunah, N. (2018). Pengaruh pemberian stimulasi oleh orang tua terhadap perkembangan bahasa pada anak usia Toddler di PAUD Asparaga Malang. Nursing News: Jurnal Ilmiah Keperawatan, 3(1).

Santrock, J. W. (2017). Psikologi Pendidikan Edisi Kedua. Kencana Prenada Media Group.

Soetjiningsih. (2014). Tumbuh Kembang Anak. Penerbit Buku Kedokteran. EGC.

Wong, D. . (2009). Buku Ajar Keperawatan Pediatric. EGC.

Yektiningsih, E., Martiningsih, M., \& Mukayaroh, A. (2010). Hubungan Pemberian Stimulasi Oleh Orang Tua Dengan Perkembangan Bahasa Pada Anak Usia Pra Sekolah (3-5 Tahun) Di Taman Kanak-Kanak Al-Fath Pare. Jurnal AKP, 1(2).

Yusuf, S. (2012). Psikologi Perkembangan Anak dan Remaja. Rosdakarya. 